\title{
O DILÚVIO MÍTICO E O MITO DA GRANDE ENCHENTE DE TUBARÃO (1974): RECORRÊNCIAS E CONVERGÊNCIAS NO IMAGINÁRIO
}

Heloisa Juncklaus Preis Moraes

Willian Corrêa Máximo

\section{PELAS VIAS DO IMAGINÁRIO}

As relações sociais, suas manifestações, artefatos e processos, são causa e efeito de dimensões imaginárias. Para além de uma mera representação imagética, o imaginário é uma atmosfera, arquetipal, atemporal e coletiva, que nutre o universo simbólico e mental dos indivíduos, estabelecendo vínculos.

As nações, os estados, as cidades e mesmo as comunidades são imaginadas, projetam imagens de comunhão, mas, sobretudo, evidenciam o lastro do imaginário em seus cotidianos, "sedimentando" identidades, identificações, laços de pertencimento, confiança e cultura, mesmo no anonimato e nas particularidades culturais de seus indivíduos.

Esta cumplicidade das comunidades imaginadas (e imaginais) se consolidam pela linguagem, por intermédio de trajetos antropológicos, que perpassam o tempo, em espaços discursivos repletos de narrativas que historicizam cada processo de significação.

Dilúvio é termo que evoca e converge um léxico de imagens e significados. Do grego Deucalião ao mito sumério de Gilgamesh, passando por Noé e os relatos cataclísmicos dos ameríndios, tal narrativa mítica perpassa gerações e, ao se (res)significar, viabiliza uma matriz imaginal: um pecado; uma comunidade; um Deus punitivo; um herói; uma aliança; e os testemunhos. Basta um relâmpago, precipitação e o sopro do 'lestada' para partilhar de uma atmosfera (re)inventada. A seguir, a partir do mito da Grande Enchente de 1974, por intermédio do teste arquetípico dos nove elementos, propõe-se identificar - na transversalidade das narrativas dos tubaronenses - elementos que presentificam o dilúvio, cujos sinais evidenciam um imaginário e uma comunidade imaginada que se reconhece por uma narrativa mítica, épica e inacabada. 
De acordo com G. Durand (2002) todo imaginário humano articula-se por meio de estruturas plurais e irredutíveis, limitadas a três classes que gravitam ao redor dos processos matriciais do 'separar' (heroico), 'incluir' (místico) e ' dramatizar' (disseminador), ou pela distribuição das imagens de uma narrativa ao longo do tempo. Assim, o imaginário constitui o conector obrigatório pelo qual forma-se qualquer representação humana. Há uma concomitância entre os gestos do corpo, os centros nervosos e as representações simbólicas. G. Durand (2002) fala dos reflexos: o da posição (ereta para o homem) corresponde à imagem de elevação, divisão, luta; reflexo da deglutição, imagens de interiorização, descida, harmonização; reflexo de copulação: imagens de ciclicidade, de ritmo, de diálogo, de progresso.

Durand (2002) divide o universo em opostos; e unindo os opostos, complementando, harmonizando. O primeiro corresponde ao regime diurno de imagens; o segundo, ao noturno, como a noite, que concilia e unifica. Os dois regimes da imagem recobrem três estruturas do imaginário, que dão resposta à questão fundamental do homem: sua mortalidade.

Os símbolos expressam a angústia e se dividem em três grandes temas. Os símbolos teriomórficos, relativos à animalidade (animal simbólico) onde encontramos o fervilhamento: repugnância primitiva diante da agitação incontrolável - arquétipo do caos; a animação: o movimento em si, incontrolável, dos grandes animais; a mordicância ou ato de morder, de devorar, outro aspecto angustiante. Os símbolos nictomórficos, relativos à noite, à escuridão, trazem situações das trevas (como a água escura). Já os símbolos catamórficos, relativos à queda, medo, dor, vertigem, castigo. Através das imagens que povoam nossa imaginação e imaginário, aqui pespecialmente a partir do elemento água, buscamos rastros do modelo primitivo. Entre o dilúvio mítico, nas diferentes culturas, e a enchente que nos propomos a estudar, há imagens arquetípicas, recorrentes e convergentes. Estamos chamando de recorrência simbólica, "o processo pelo qual determinado mitema" atravessa a narrativa (textual ou imagética), de modo a reiterar seu nível de pertença a um registro simbólico específico ou estrutura de sensibilidade" (SANTOS e ALMEIDA, 2012, p. 76). E, de maneira muito

\footnotetext{
${ }^{1}$ Na obra de Durand, mitema é a menor unidade do discurso miticamente significativo, ou seja, está no campo das significações (e não sintática, como o termo em Levi-Strauss) (TURCHI, 2003, p. 40).
} 
recorrente, a enchente aparece como símbolo de pertencimento na narrativa e nas ações e práticas cotidianas dos tubaronenses que, inclusive, já se tornaram marcas desta comunidade. O mitema enchente é marca de identidade desta comunidade local imaginada, em que os vínculos de pertencimento ancoram-se nas memórias vividas ou herdadas. A nossa investigação busca, sob o viés do imaginário, identificar estas marcas míticas e arquetipais.

A enchente aparece, na nossa visão, não apenas como traço simbólico do imaginário local, mas também como marca de uma ancestralidade, aqui, através do mito do dilúvio. Durand (2002, p.62) define o mito como "um sistema dinâmico de símbolos, arquétipos e esquemas, sistema dinâmico que, sob impulso de um esquema, tende a compor-se em narrativa. O mito é já um esboço de racionalização, dado que utiliza o fio do discurso, no qual símbolos se resolvem em palavras e os arquétipos em ideias".

A água, para além de uma substância química cujas moléculas são formadas por dois átomos de hidrogênio e um de oxigênio, é uma experiência onírica (dos sonhos e para além de), ambivalente. É um arquétipo, tem raiz ancestral.

$O$ insconsciente marítimo (e mais do que isso pela potência simbólica que dispõe, o imaginário hídrico, marítimo) é, portanto, um inconsciente falado, um inconsciente que se dispersa em narrativas de aventuras, um inconsciente que não dorme. Para Bachelard (1998), antes de ser um espetáculo consciente, toda paisagem é uma experiência onírica. A água, como um dos quatro elementos chave estudados pelo autor, guarda o início, a vida, a morte e a renovação em sua substância. Ela (a água) que coloca em oposição o sagrado (e a vida religiosa) e o profano (a vida secular); a água oculta o céu, sendo metáfora do caos, da transformação, da resiliência.

A água mistura, em seus símbolos, reminiscências e devaneios divinatórios. Podemos traçar relação com o destino do ser humano que, assim como da água, corre, caracterizando-se como um elementos transitório. É, segundo Bachelard (1998), a metamorfose ontológica essencial entre o fogo e a terra. A morte cotidiana não é a morte exuberante do fogo que perfura o céu com suas flechas; a morte cotidiana é a 
morte da água. A água corre sempre, a água cai sempre, acaba sempre em sua morte horizontal.

A água, fonte de vida, assume um rancor, muda de sexo. De feminina, torna-se má, masculina, voraz. A água silenciosa, água sombria, água dormente, água insondável, quantas lições materiais para uma meditação da morte. Quantos atitudes imaginais para romper com os semblantes do tempo. Para vencer a finitude e, principalmente, para manter o fio discursivo que permite, mitologicamente, ter vencido o dilúvio, a fúria das águas de um rio.

Em Tubarão, basta um vento noturno para que a água que volte a rugir, bastará um raio para dialogarmos com o divino, bastará um raio de lua, muito suave, muito pálido, para que o fantasma caminhe de novo sobre as ondas, do mar e do rio. Segundo Eliade (1992), o mito conta uma história sagrada; ele relata um acontecimento ocorrido no tempo primordial, o tempo fabuloso do 'princípio'; o mito é considerado uma história sagrada e, portanto, uma 'história verdadeira', porque sempre se refere a realidades.

Eliade (1992, p.60) esclarece que o tempo do mito é o tempo total e o evento fundador pode ser ressuscitado a cada momento da vida. Aí estaria a essência do sagrado. Presente a hierofania, o episódio mítico fundador, o mito irriga a história, lhe dá sentido. O mito fundador configura-se como uma ponte. A imagem simbólica é ativada, dotada de um poder imediato de transformação daquele que a vê, e logo a vive. As imagens simbólicas são reagrupadas em relatos organizados, os mitos.

\section{COMUNIDADE LOCAL IMAGINADA}

A partir da Teoria do Imaginário (DURAND, 2002), que legitima imagens e imaginação enquanto potência simbólica, e sob o método da sociologia compreensiva (MAFFESOLI, 2007), que contextualiza fenômenos sociais e o imaginário no cotidiano, este estudo instrumentaliza-se a partir do teste arquetipal dos nove elementos (AT-9), modelo experimental de Yves Durand. O teste aponta elementos de universos míticos (ELIADE, 1992), representados através de nove estímulos arquetípicos: personagem, queda, espada, refúgio, monstro, cíclico, água, anima e fogo. 
Em Tubarão, a amostra contemplou representantes de nativos e diaspóricos: dois residentes, desde a enchente de 1974; e dois emigrantes, pós-74. A primeira etapa do AT-9 levou o respondente a representar, em até $30 \mathrm{~min}$., algum ou todos os elementos arquetípicos; a segunda, convidando-o a redigir sobre o desenho; a terceira, com aplicação de questionário sobre a ideia central, predileção e/ou eliminação de algum dos nove elementos, participação (caso estivesse em cena), atitude no contexto representado, além da conclusão da história; a quarta etapa previu o preenchimento de um quadro síntese com os nove elementos, formas de representação e funções simbólicas. Experienciou-se ainda a inclusão de uma quinta fase: entrevista, a partir de outras nove 'iscas semânticas': Tubarão; 1974; chuva; rio; rádio Tubá; vento leste (ou lestada); Irmoto; Catedral; e solidariedade; narrativas que convergem 'bacias semânticas' (SILVA, 2003) para uma comunidade imaginada (ANDERSON, 2006) uma matriz - possibilitando sentimento de pertença e a partilha da angústia, colocando o dilúvio mítico e a cheia tubaronense de 74 num mesmo campo imaginal (DURAND, 2002).

A Teoria do Imaginário (DURAND, 2002) reposicionou o complexo e pouco compreendido universo da psique humana. $O$ inconsciente, inspiração para 0 desenrolar do trajeto antropológico do imaginário durandiano, manifesta-se por arquétipos - 'marcas-impressão' de caráter arcaico - segundo Jung (1998). São os arquétipos que pautam imagens (PITTA, 2005) e os símbolos possibilitam o surgimento dos mitos (ELIADE, 1992) enquanto um sistema dinâmico (DURAND, 2002), uma narrativa de sentidos múltiplos (ROCHA, 2012).

O mito é um vetor social, que impulsiona e é impulsionado pelas relações e pelo meio. Pelo mito a história 'sagrada' se (re)atualiza, é transmitida e preservada (ELIADE, 1992). Nesta atmosfera imaginal, (DURAND, 2002), não há sentido, há movimento e coerência. O dilúvio é uma narrativa mítica que preserva um lugar comum - dos gregos, aos sumérios, passando pelos mitos hebraicos, depois ameríndios até os 'Noés' europeus.

A água entra em cena enquanto elemento arquetipal: vida, purificação e fertilização para viscosidade, punição e resiliência (BACHELARD, 1998). Para além de um evento cíclico, inundações são carregadas de pregnância simbólica (DURAND, 
2002), o que não difere da cheia de Tubarão. Em 1974, o município sofria sua terceira enchente; inúmeros desabrigados e duzentos mortos (VETTORETTI, 1992). De lá para cá, formou-se um mito: o mito da Grande Enchente, uma narrativa dramática, (re)contada e (re)memorada; um novo léxico para o rio que lhe confere nome (Tubarão, do tupi guarani Tuba-Nharô, pai feroz) - (VETTORETTI, 1992): belo, navegável, fonte de vida para um monstro voraz que, sob os efeitos do 'lestada' é sinônimo de enchente.

A aplicação do AT-9 revelou detalhes importantes da estrutura mítica nos microuniversos dos entrevistados, do imaginário local. Nativos e emigrantes, na primeira etapa do teste, embrenharam-se em seus traçados, com histórias e personagens distintos. $\mathrm{Na}$ segunda etapa, nas redações, destaque para a necessidade da interrelação entre cada representação pictórica. A terceira etapa, trouxe à tona a predileção pelo refúgio (aconchego) e pela espada, eliminando a queda (enquanto elemento arquetípico da vertigem), e do monstro (noite inquietante e morte). Na quarta etapa, no quadro síntese e em comum, a capacidade de classificar os símbolos e ordenar emoções. A quinta etapa, proposta por esta pesquisa, inseriu outras nove 'iscas' semânticas, que nos auxiliaram a conhecer, mesmo sob espaços e locais distintos na aplicação do experimento, a partilha de um mesmo momento, convergindo microuniversos míticos para uma matriz, uma comunidade imaginada, consubstanciando um campo simbólico comum e, portanto, análogo à narrativa do dilúvio mítico: a ocupação desordenada, sinônimo do pecado; das comunidades, uma pré e outra pós-74 - esta última imaginada que os faz reviver o mito da Grande enchente; a força das águas, encomenda de um Deus punitivo; Irmoto, jovem prefeito à época, considerado um 'herói' local; os testemunhos, que reverberam em cada diálogo local e nos eventos que relembram o fato, fazendo-os partilhar de uma mesma atmosfera; e uma aliança, uma cidade reconstruída pela solidariedade pós-enchente, que alimenta o paradoxal compromisso de não cicatrizar em favor da coerência comunitária imaginal que os faz pertencer.

\section{CONSIDERAÇÕES FINAIS}


Para além da materialidade, inundações são narrativas míticas impregnadas de imaginário. O AT-9, sendo adicionado de uma quinta etapa proposta, evidenciou - a partir do mito da Grande Enchente tubaronense de 1974 e na transversalidade das narrativas - elementos que presentificam o dilúvio mítico, por meio de imagens e símbolos que também acessam uma comunidade imaginada. Percebeu-se pelos estímulos arquetípicos do protocolo e pelas iscas semânticas, campos simbólicos comuns, potencial motor e criador nos universos míticos (individuais e coletivos), perpetuação de narrativas e, sobretudo, sintonia entre o mito local e o dilúvio universal; conexões que reforçam a ideia 'do eterno retorno' (ELIADE, 1992), uma vez que cessar tais narrativas (e angústias) seria sinônimo de perda da identidade. Logo, as recorrências e convergências do imaginário tem no dilúvio mítico uma matriz imaginal de identidade local após uma enchente. A grande enchente que se mantem presente no imaginário social que tem sua expressão nas narrativas, atos e ritos do cotidiano local. E esta recorrência simbólica funciona como elo de pertencimento.

\section{REFERÊNCIAS}

ANDERSON, Benedict. Comunidades Imaginadas: reflexões sobre a origem e a expansão do nacionalismo. Lisboa: edições 70, 2005.

BACHELARD, Gaston. A água e os sonhos: ensaio sobre a imaginação da matéria. São Paulo: Martins Fontes, 1998.

DURAND, Gilbert. As estruturas antropológicas do imaginário: introdução à arquetipologia geral. São Paulo: Martins fontes, 2002.

DURAND, Y. A Exploração do Imaginário: Introdução a modelização dos universos míticos. Trad. Loureiro, A M L. Brasília: 2002.

ELIADE, Mircea. Mito do eterno retorno. São Paulo: Mercuryo, 1992. 147p HALL, Stuart; SOVIK, Liv. Da diáspora: identidades e mediações culturais. Belo Horizonte: Ed. UFMG, 2003.

JUNG, C. G. (Carl Gustav). A vida simbólica: escritores diversos. Petrópolis: Vozes, 1998.

LEGROS, Patrick et al. Sociologia do imaginário. Porto Alegre: Sulina, 2007.

MACHADO, César do Canto. Tubarão 1974: fatos e relatos da grande enchente. Tubarão: Unisul, 2005. 
MAFFESOLI, Michel. O conhecimento comum: introdução à sociologia compreensiva. São Paulo: Sulina, 2007.

PITTA, Danielle Perin Rocha. Iniciação à teoria do imaginário de Gilbert Durand. Rio de Janeiro: Atlântica Editora, 2005.

ROCHA, Everaldo P. Guimarães. O que é mito. São Paulo: Brasiliense, 2012.

SANTOS, Marcos Ferreira; ALMEIDA, Rogério de. Aproximações ao imaginário: bússola de investigação poética. São Paulo: Képos, 2012.

SILVA, Juremir Machado da. Tecnologias do imaginário. Porto Alegre: Sulina, 2003.

TURCHI, Maria Zaira. Literatura e antropologia do imaginário. Brasília: Editora da UnB, 2003.

VETTORETTI, Amadio. História de Tubarão: das origens ao século XX. Tubarão: Prefeitura Municipal, 1992. 430 p. 